\title{
New Record of Two Apokeronopsis Species (Ciliophora: Urostylida: Pseudokeronopsidae) from Korea
}

\author{
Jae-Ho Jung, Ye-Seul Baek, Gi-Sik Min* \\ Department of Biological Sciences, Inha University, Incheon 402-751, Korea
}

\begin{abstract}
The morphology of the two marine hypotrichous ciliates Apokeronopsis bergeri and A. ovalis, isolated from the Yellow Sea, Korea, are described based on live and protargol-impregnated specimens. It is the first time that these species have been recorded in Korea. In addition, the small subunit ribosomal RNA gene was sequenced for comparison with the public database. The genus Apokeronopsis has recently been established in the family Pseudokeronopsidae, and the two congeners of the Korean population share the following characteristics: one row of one or more buccal cirri; usually two frontoterminal cirri; midventral complex composed of two distinctly separated rows; one left and one right marginal row; number of transverse cirri, more than eight; absence of caudal cirri; two types of cortical granules. Apokeronopsis bergeri differs from A. ovalis primarily in body shape (fusiform vs. oval form), size (usually $260 \times 80 \mu \mathrm{m}$ vs. $160 \times 55 \mu \mathrm{m}$ ), type II cortical granules (oval vs. round shape; yellow-green vs. mostly colourless and only a few yellow-green in colour), and morphometric data (75-106 vs. 53-70 in adoral membranelles; 37-47 vs. 24-36 in frontal cirri; 9-15 vs. 1-2 in buccal cirri), as well as molecular data (2.87\% of pairwise distance).
\end{abstract}

Keywords: Apokeronopsis bergeri, Apokeronopsis ovalis, marine ciliate, morphology, SSU rRNA gene, Korea

\section{INTRODUCTION}

The genus Apokeronopsis in the family Pseudokeronopsidae was recently established by Shao et al. (2007). Based on morphology and morphogenesis, the genus was split from the genus Thigmokeronopsis (Shao et al., 2007). In addition to the previous morphological studies, recently, the taxonomical status of Apokeronopsis has been well supported from molecular phylogenetic analysis as well(Yi et al., 2008; Chen et al., 2011). To date six species of this genus have been described: A. crassa (Claparède and Lachmann, 1858) as a type species, A. antarctica (Petz, 1995), A. bergeri Li et al., 2008, A. ovalis (Kahl, 1932), A. sinica Liu et al., 2009, and A. wrighti Long et al., 2008 (see Shao et al., 2007; Li et al., 2008; Long et al., 2008; Shao et al., 2008; Liu et al., 2009).

In this study, we collected two marine ciliates, $A$. bergeri and A. ovalis, from Korea, and described them based on live and protargol-impregnated specimens. In addition, sequences of the small subunit ribosomal RNA (SSU rRNA) gene were also obtained for comparison with known NCBI sequences. The two species were first reported in Korea, and morpho- logical and molecular data of the Korean population coincided with those of previous studies.

\section{MATERIALS AND METHODS}

\section{Sample collection and identification}

Specimens of Apokeronopsis bergeri were collected from Incheon Harbor (salinity, $28.5 \%$; temperature, $15^{\circ} \mathrm{C} ; 37^{\circ} 26^{\prime} \mathrm{N}$, $126^{\circ} 35^{\prime} \mathrm{E}$ ), and those of $A$. ovalis were collected from Baengyeongdo Island (salinity, $30 \%$; temperature, $14.5^{\circ} \mathrm{C} ; 37^{\circ} 57^{\prime} \mathrm{N}$, $124^{\circ} 43^{\prime} \mathrm{E}$ ) from the Yellow Sea, Korea, in November 2010. By a plankton net the samples were collected from benthic substrates or stirred water on bottom sediments.

Cultures were maintained in both Petri dishes and $50 \mathrm{~mL}$ tissue culture flasks (Greiner Bio-one, Frickenhausen, Germany). Rice grains were used for enrichment of bacterial growth in the culture, and the enriched bacteria were grazed on by ciliates as a food. Living specimens were observed under a light microscope (Leica DM2500, Wetzlar, Germany) at 50 to 1,000 magnifications. Protargol impregnation was (c) This is an Open Access article distributed under the terms of the Creative Commons Attribution Non-Commercial License (http://creativecommons.org/ licenses/by-nc/3.0/) which permits unrestricted non-commercial use, distribution, and reproduction in any medium, provided the original work is properly cited.

\footnotetext{
*To whom correspondence should be addressed

Tel: 82-32-860-7692, Fax: 82-32-874-6737

E-mail: mingisik@inha.ac.kr
} 
performed in order to reveal their infraciliature (Foissner, 1991).

Terminology and classification were mainly followed according to Berger (2006) and Lynn (2008).

\section{DNA sequence determination}

Extraction of genomic DNAs from single specimens of each species was performed according to the manufacturer's protocol, using a RED-Extract-N-Amp Tissue PCR Kit (Sigma, St. Louis, MO, USA). New EukA (5'-CTG GTT GAT YCT GCC AGT-3'), modified from Medlin et al. (1988) and LSU rev3 (Sonnenberg et al., 2007) primers were used for PCR amplification of the nearly complete SSU rRNA gene. Optimized conditions for this process were as follows: denaturation at $94^{\circ} \mathrm{C}$ for $3 \mathrm{~min}$ followed by 35 cycles of denaturation at $94^{\circ} \mathrm{C}$ for $30 \mathrm{sec}$, annealing at $58^{\circ} \mathrm{C}$ for $30 \mathrm{sec}$, extension at $72^{\circ} \mathrm{C}$ for $4 \mathrm{~min}$, and then a final extension step at $72^{\circ} \mathrm{C}$ for 7 min. The QIAquick ${ }^{\circledR}$ PCR Purification Kit (QIAGEN, Chatsworth, CA, USA) was used for purification of PCR products. Two internal primers were used for sequencing: $18 \mathrm{~S}+810$, 5'-GCC GGA ATA CAT TAG CAT GG-3' and 18S-300, 5'-CAT GGT AGT CCA ATA CAC TAC-3'. An ABI 3700 sequencer (Applied Biosystems, Foster City, CA, USA) was used for sequencing. Sequencing fragments of the SSU rRNA gene were combined via BioEdit (Hall, 1999) and were aligned according to Clustal X 1.81 (Jeanmougin et al., 1998). Mega 3.1 (Kumar et al., 2004) was used for calculation of genetic distance, employing the Kimura two-parameter distance method (Kimura, 1980). SSU rRNA gene sequences belonging to the genus Apokeronopsis were retrieved from the GenBank database (see Table 3 for GenBank accession numbers).

\section{SYSTEMATIC ACCOUNTS}

Phylum Ciliophora Doflein, 1901

Class Spirotrichea Bütschli, 1889

Order Urostylida Jankowski, 1979

Family Pseudokeronopsidae Borror and Wicklow, 1983

1*Genus Apokeronopsis Shao et al., 2007

2*Apokeronopsis bergeri Li et al., 2008

(Table 1, Figs. 1A-F, 2)

Apokeronopsis bergeri $\mathrm{Li}$ et al., 2008: 208, figs. 1-8.

Materials examined. One population was obtained from Incheon Harbor on the 2nd of November, 2010.

Description. Size in life usually $260 \times 80 \mu \mathrm{m}$ (Figs. 1A,
2A). Body slightly contractile and flexible (Fig. 2B, C); fusiform shape with both ends broadly rounded; dorsoventrally flattened. Contractile vacuole located on the left side of the anterior $1 / 3$, approximately $15 \mu \mathrm{m}$ in diameter (Figs. 1A, 2B, arrow). Cells appeared yellow green to green in colour under low magnification. Cytoplasm opaque and colourless (Fig. 2D). Macronuclei composed of about 200 nodules, each one oval shaped (Figs. 1F, 2G).

Two types of cortical granules: type I very small, $\mathrm{ca}$. 0.3 $\mu \mathrm{m}$ across and colourless, arranged on a line longitudinally, distributed over the entire body (Figs. 1B, 2D, arrowhead); type II $c a$. $2 \mu \mathrm{m}$ across, oval shape, and yellow green in colour, densely and irregularly distributed over the entire body (Figs. 1B, arrow; C, D; 2D, arrow).

Distinct adoral zone of membranelles, about $1 / 3$ of the cell length, formed question mark, composed of about 85 membranelles; base of the longest membranelles are about $10 \mu \mathrm{m}$ wide (Fig. 1A, E). Paroral and endoral membranes are almost equal in length and spatially crossed at proximal end on different planes (Fig. 1E).

Most somatic cirri are relatively fine, $c a$. $15 \mu \mathrm{m}$ in length. Bicorona of frontal cirri slightly enlarged, composed of 42 cirri, extending consecutively to midventral complex. Midventral complex distinctly separated rows, composed of 77 cirri, terminating near transverse cirri. The cirri of left row of both bicorona and midventral complex relatively smaller than those of right one (Fig. 1E). Usually two frontoterminal cirri, located on the distal end of the adoral zone (Fig. 1E, arrow). One row of buccal cirri consisting of 9-15, alongside of the paroral membrane. Cirri in left and right marginal rows narrowly spaced, and separated on the posterior end of the cell with a slightly conspicuous gap. Transverse cirri arranged in a J-shaped row, composed of 11-18 cirri. Dorsal cilia ca. $5 \mu \mathrm{m}$ long; invariably three complete dorsal kineties (Fig. 2E, arrows).

Distribution. China and Korea (this study).

Remarks. In terms of the infraciliature, Apokeronopsis sinica mostly resembles $A$. bergeri. However, the former can be distinguished from the later by the following characteristics: body shape (slender ellipsoid with widely rounded anterior end vs. fusiform with narrowing at cell ends), number of adoral membranelles (41-62 vs. 75-106), buccal cirri (1-6 vs. 9-15), frontal cirri (18-29 vs. 37-47), and transverse cirri (8-13 vs. 11-18) (Shao et al., 2008).

The Korean population of $A$. bergeri corresponds well with the original description by Li et al. (2008) and the ranges of characteristics in the morphometric comparisons are highly overlapped (Table 1). However, the body size of the Korean population is slightly smaller than that of the Chinese

Korean name: ${ }^{1 *}$ 박각모하모충속(신칭), ${ }^{2 *}$ 황색박각모하모충 (신칭) 
Table 1. Morphometric characterization of Apokeronopsis bergeri

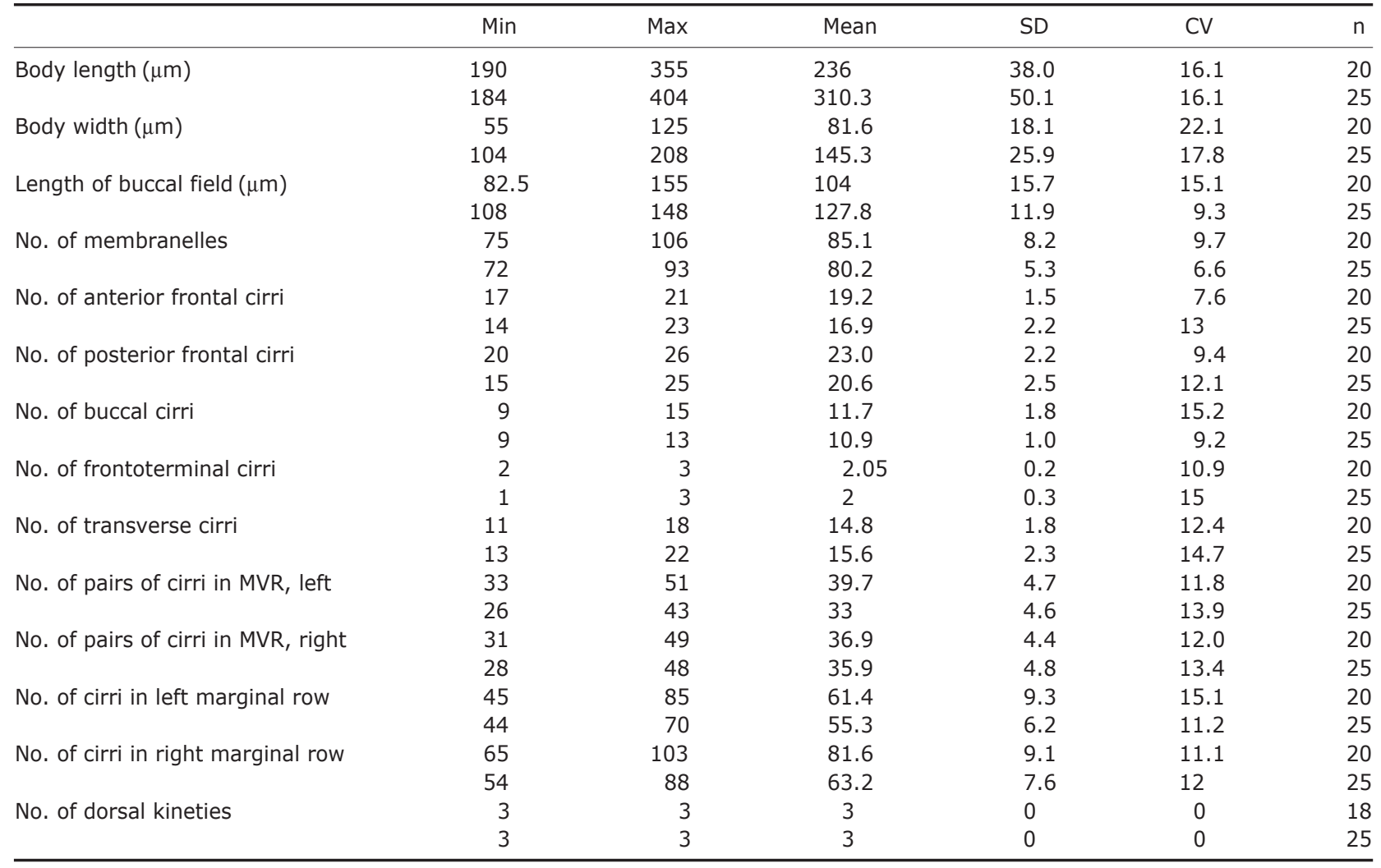

All data, including those from the Korean population (upper line) and Chinese population (lower line) are based on protargol-impregnated specimens. Data from the Chinese population (lower line) are cited from Li et al. (2008).

MVR, midventral row; Min, minimum; Max, maximum; Mean, arithmetic mean; SD, standard deviation; CV, coefficient of variation in \%; n, number of individuals examined.

population (ca. $260 \times 80$ vs. $300 \times 80 \mu \mathrm{m}$ in vivo), and the type II granules of the Chinese specimen are flattened and biconcave (similar to erythrocytes of mammals), while those of Korean specimens are slightly flattened and convex.

The SSU rRNA gene sequence of $A$. bergeri is $1,748 \mathrm{bp}$ in length (GenBank accession no: JF718644). Inter-specific pairwise distances between $A$. bergeri and congeners are more than $2 \%$, however the intra-specific distance within $A$. bergeri is $0.17 \%$ (Table 3 ).

\section{1*Apokeronopsis ovalis (Kahl, 1932)}

(Table 2, Figs. 1G-J, 3)

Holosticha (Keronopsis) ovalis Kahl, 1932: 575, fig. 110-2. Holosticha (Keronopsis) ovalis forma arenivora Kahl, 1932: 575, fig. 103-1.

Pseudokeronopsis ovalis Borror and Wicklow, 1983: 124; Berger, 2006: 968, fig. 189.

Apokeronopsis ovalis Shao et al., 2008: 363, figs. 1-69.
Materials examined. One population was obtained from Baengyeongdo Island on the 16th of November, 2010.

Description. Size in life usually $160 \times 55 \mu \mathrm{m}$ (Figs. $1 \mathrm{G}$, 3A-D). Body slightly contractile and flexible (Fig. 3B-D); shape in oval form; dorsoventrally flattened. Contractile vacuole located on the left side of the anterior one third of body, about $10 \mu \mathrm{m}$ in diameter (Figs. 1G, 3C, arrow). Cells appeared colourless to grayish in colour under low magnification. Cytoplasm opaque and colourless (Fig. 3A-D). Macronuclei usually 150 nodules, each one oval in shape (Figs. 1J; 3I, arrow).

Two types of cortical granules: type I very small, about $0.2 \mu \mathrm{m}$ across and colourless, arranged on a line longitudinally, distributed over the entire body (Figs. 1H, arrowhead; $3 \mathrm{~F}$, arrowhead); type II granules $1.5 \mu \mathrm{m}$ in diameter, round shape, and mostly colourless and only a few yellow greencoloured, densely and irregularly distributed over the entire body (Figs. 1H, arrow; 3E, F, arrow)

Korean name: ${ }^{1 *}$ 난형박각모하모충 (신칭) 

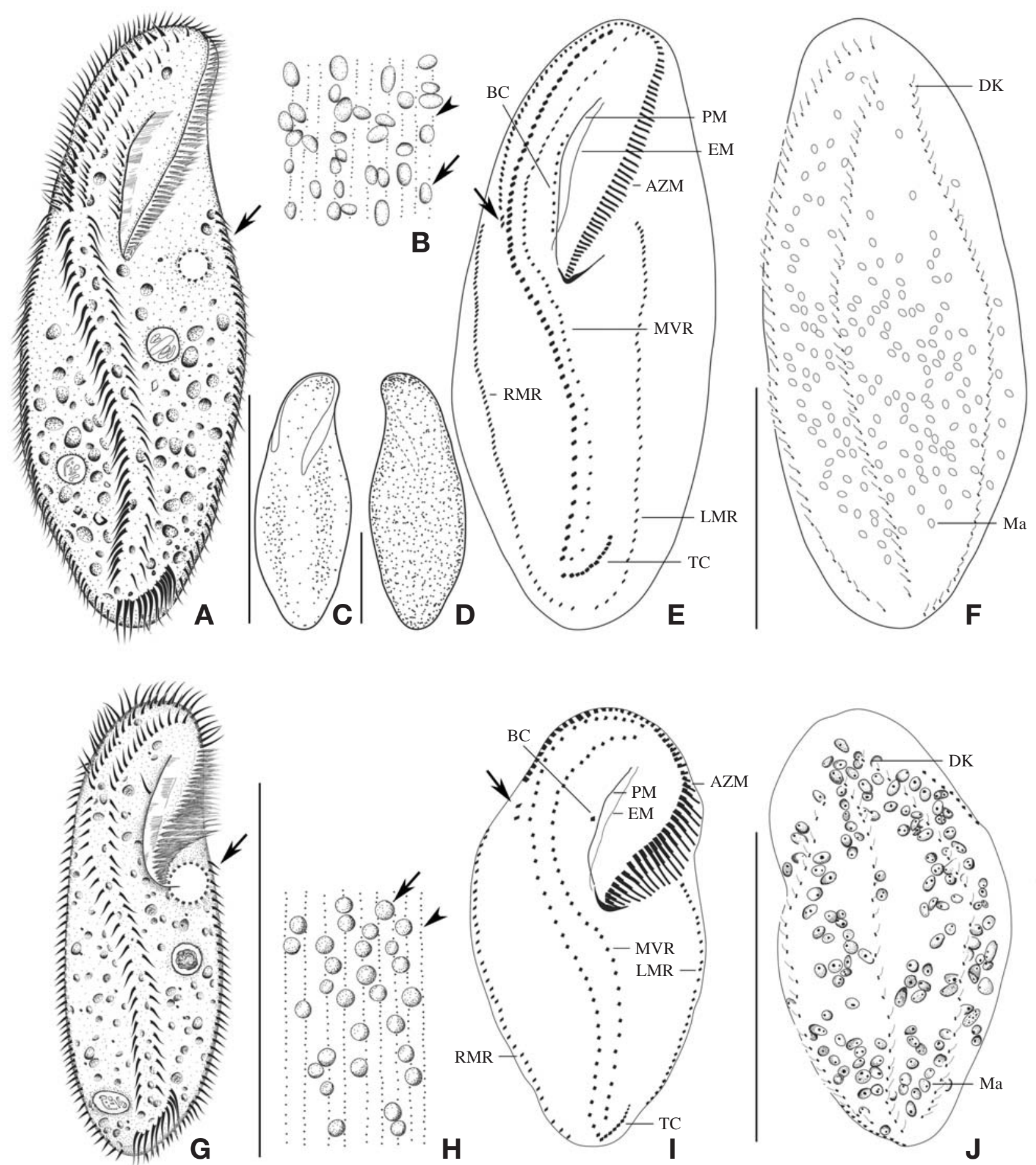

Fig. 1. Morphology and infraciliature of Apokeronopsis bergeri and $A$. ovalis from live $(A-D, G, H)$ and after protargol impregnation $(E, F, I, J)$. A-F, Apokeronopsis bergeri: A, Ventral view of live, arrow indicates the contractile vacuole; $B$, Two types of densely distributed granules, arrow and arrowhead show the granules, respectively; larger granules scattered throughout the body, ventral (C) and dorsal (D) views; E, F, Infraciliature of ventral (E) and dorsal (F) sides, arrow in (E) to show frontoterminal cirri; G-J, Apokeronopsis ovalis: $G$, Ventral view of live, arrow indicates the contractile vacuole; $H$, Densely distributed granules, arrow and arrowhead show the two types of granules, respectively; I, J, Infraciliature of ventral (I) and dorsal (J) sides, arrow in (I) to show frontoterminal cirri. AZM, adoral zone of membranelles; BC, buccal cirri; DK, dorsal kineties; EM, endoral membrane; LMR, left marginal row; Ma, macronuclei; MVR, midventral row; PM, paroral membrane; RMR, right marginal row; TC, transverse cirri. Scale bars: $100 \mu \mathrm{m}$. 


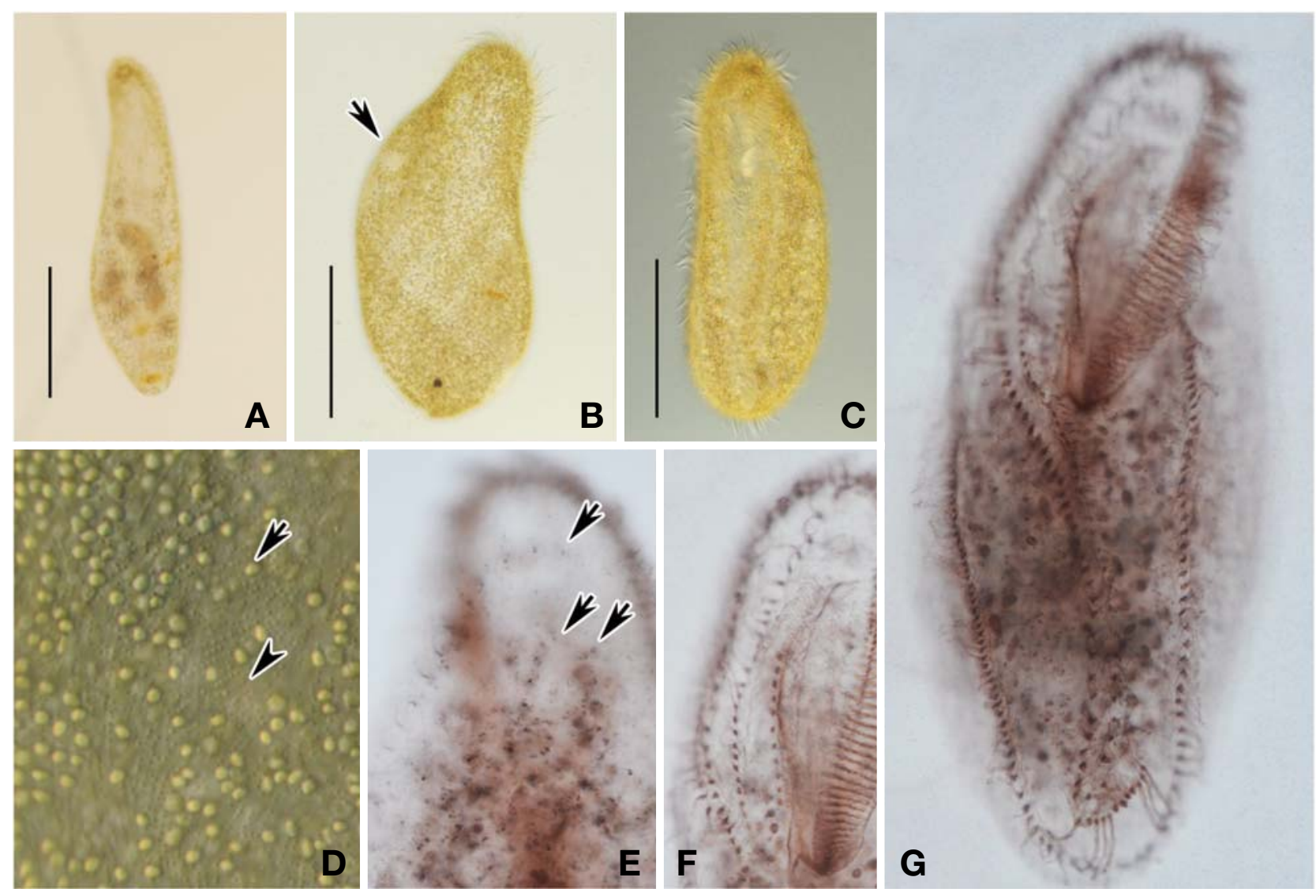

Fig. 2. Morphology and infraciliature of Apokeronopsis bergeri from live $(A-D)$ and after protargol impregnation (E-G). Dorsal $(A, B)$ and ventral ( $C, D)$ views of live, $(B)$ arrow indicates the contractile vacuole; C, Body shape slightly contractile and flexible; $D$, Arrow and arrowhead indicate the two types of granules, respectively; Dorsal $(E)$ and ventral $(F, G)$ views of protargol-impregnated specimen, (E) arrows mark the invariable three dorsal kineties; F, Frontal cirri (bicorona) and one row of buccal cirri; G, General ciliature of the specimen, usually 200 densely scattered macronuclear nodules. Scale bars: $100 \mu \mathrm{m}$.

Distinct adoral zone of membranelles, about $1 / 3$ of cell length, formed question mark, consisting of about 62 membranelles; base of the longest membranelles is about $15 \mu \mathrm{m}$ wide (Fig. 1I). Paroral and endoral membranes are almost equal in length and spatially crossed on the proximal end (Fig. 1I).

Most somatic cirri are relatively fine, about $10 \mu \mathrm{m}$ in length. Bicorona of frontal cirri slightly enlarged, composed of 30 cirri, connecting to the midventral complex with an inconspicuous gap. Midventral complex consisted of about 52 cirri, terminating near transverse cirri. Invariably, two frontoterminal cirri located on the distal end of the adoral zone (Fig. 1I, arrow). Buccal cirri consisting of 1-2 arranged in a line beside the paroral membrane (Figs. 1I, 3K). Transverse cirri J-shaped, and composed of 9-14 (Figs. 1I, 3L). Left marginal row terminating on the posterior dorsal side, composed of 30-47 cirri; right marginal row commencing on the anterior dorsal side, consisting of 38-55 cirri. Dorsal kineties usually composed of three (Figs. 1J; 3J, arrows); cilia about $5 \mu \mathrm{m}$ in length (Figs. 1J; 3F, double-arrowhead).

Distribution. Germany, China, and Korea (this study).

Remarks. In comparison with the congeners, Apokeronopsis sinica appears to be the closest species to A. ovalis. However, the former can be separated from the latter by body shape (slender ellipsoid vs. oval), the anterior position of the right marginal row (ventral vs. dorsal), and the colour of the larger cortical granules (mostly colourless and a few vermeil vs. mostly colourless and a few yellow-green) (Liu et al., 2009).

The population of Apokeronopsis ovalis in this study corresponds well with the description of combining authors Shao et al. (2008). A morphometric comparison among the Korean and two Chinese populations (Shao et al., 2008) is shown in Table 2, and most features are consistent among three populations. Shao et al. (2008) described the Chinese populations having one to five buccal cirri (vs. 1-2 in Korean), and are brown to dark brown in colour (vs. colourless to grayish in 
Jae-Ho Jung, Ye-Seul Baek, Gi-Sik Min

Table 2. Morphometric characterization of Apokeronopsis ovalis

\begin{tabular}{|c|c|c|c|c|c|c|}
\hline & Min & Max & Mean & SD & CV & $\mathrm{n}$ \\
\hline \multirow[t]{3}{*}{ Body length $(\mu \mathrm{m})$} & 105.6 & 155 & 134.7 & 12.9 & 9.6 & 20 \\
\hline & 120 & 175 & 145.3 & 16.9 & 11.6 & 16 \\
\hline & 132 & 181 & 158.8 & 14.1 & 8.9 & 25 \\
\hline \multirow[t]{3}{*}{ Body width $(\mu \mathrm{m})$} & 50 & 82.5 & 66.0 & 9.7 & 14.6 & 20 \\
\hline & 55 & 90 & 72.8 & 8.2 & 11.2 & 16 \\
\hline & 60 & 100 & 83 & 10.2 & 12.3 & 25 \\
\hline \multirow[t]{3}{*}{ Length of buccal field ( $\mu \mathrm{m})$} & 51.2 & 77.5 & 65.0 & 7.7 & 11.8 & 20 \\
\hline & 53 & 75 & 63.9 & 7.1 & 11.1 & 15 \\
\hline & 64 & 88 & 75.6 & 5.9 & 7.8 & 25 \\
\hline \multirow[t]{3}{*}{ No. of membranelles } & 53 & 70 & 61.6 & 4.8 & 7.7 & 19 \\
\hline & 43 & 66 & 54.8 & 5.5 & 10 & 16 \\
\hline & 53 & 65 & 57.9 & 3.3 & 5.7 & 23 \\
\hline \multirow[t]{3}{*}{ No. of cirral pairs in bicorona } & 12 & 18 & 15.2 & 1.8 & 12.1 & 19 \\
\hline & 10 & 19 & 14.5 & 2.4 & 16.7 & 15 \\
\hline & 12 & 18 & 15.4 & 1.6 & 10.6 & 24 \\
\hline \multirow[t]{3}{*}{ No. of buccal cirri } & 1 & 2 & 1.35 & 0.5 & 36.2 & 20 \\
\hline & 1 & 4 & 1.8 & 1.1 & 64.3 & 16 \\
\hline & 4 & 5 & 4.3 & 0.5 & 10.9 & 23 \\
\hline \multirow[t]{3}{*}{ No. of frontoterminal cirri } & 2 & 2 & 2 & 0 & 0 & 19 \\
\hline & 2 & 2 & 2 & 0 & 0 & 16 \\
\hline & 2 & 2 & 2 & 0 & 0 & 25 \\
\hline \multirow[t]{3}{*}{ No. of transverse cirri } & 9 & 14 & 11.5 & 1.6 & 13.8 & 17 \\
\hline & 9 & 16 & 11.3 & 1.7 & 15 & 16 \\
\hline & 8 & 13 & 10.8 & 1.1 & 10.1 & 22 \\
\hline \multirow[t]{3}{*}{ No. of pairs of cirri in MVR, left } & 19 & 32 & 25.5 & 3.3 & 13.1 & 18 \\
\hline & 16 & 28 & 20.6 & 3.6 & 17.3 & 17 \\
\hline & 18 & 28 & 22.3 & 2.8 & 12.6 & 18 \\
\hline \multirow[t]{3}{*}{ No. of pairs of cirri in MVR, right } & 20 & 32 & 26.8 & 2.9 & 10.9 & 18 \\
\hline & 16 & 29 & 21.4 & 3.7 & 17.2 & 17 \\
\hline & 19 & 28 & 22.5 & 2.7 & 11.9 & 18 \\
\hline \multirow[t]{3}{*}{ No. of cirri in left marginal row } & 30 & 47 & 37.6 & 4.8 & 12.8 & 19 \\
\hline & 24 & 40 & 32.5 & 5.1 & 15.6 & 17 \\
\hline & 31 & 43 & 35.6 & 3.7 & 10.3 & 19 \\
\hline \multirow{3}{*}{ No. of cirri in right marginal row } & 38 & 55 & 47.6 & 4.0 & 8.3 & 20 \\
\hline & 30 & 56 & 41.7 & 7 & 16.8 & 16 \\
\hline & 36 & 51 & 43.2 & 3.4 & 7.8 & 19 \\
\hline \multirow[t]{3}{*}{ No. of dorsal kineties } & 3 & 4 & 3.1 & 0.3 & 8.7 & 14 \\
\hline & 3 & 4 & 3.2 & 0.4 & 13.6 & 13 \\
\hline & 3 & 3 & 3 & 0 & 0 & 18 \\
\hline
\end{tabular}

All data including those from the Korean population (first line) and the Chinese population (second and third line are based on protargol-impregnated specimens. Data from the Chinese populations are cited from Shao et al. (2008).

MVR, midventral row; Min, minimum; Max, maximum; Mean, arithmetic mean; SD, standard deviation; CV, coefficient of variation in \%; $\mathrm{n}$, number of individuals examined.

Table 3. Pairwise distance of SSU rRNA gene sequences among Apokeronopsis congeners were calculated using the Kimura twoparameter distance

\begin{tabular}{|c|c|c|c|c|c|c|}
\hline & $\begin{array}{c}\text { A. bergeri } \\
\text { (DQ777742) }\end{array}$ & $\begin{array}{l}\text { A. bergeri } \\
\text { (this study) }\end{array}$ & $\begin{array}{c}\text { A. crassa } \\
\text { (DQ359728) }\end{array}$ & $\begin{array}{c}\text { A. ovalis } \\
\text { (EU930048) }\end{array}$ & $\begin{array}{l}\text { A. ovalis } \\
\text { (this study) }\end{array}$ & $\begin{array}{c}\text { A. wrighti } \\
\text { (EU417963) }\end{array}$ \\
\hline \multicolumn{7}{|l|}{ A. bergeri (DQ777742) } \\
\hline A. bergeri (this study) & $0.17 \%$ & & & & & \\
\hline A. crassa (DQ359728) & $2.46 \%$ & $2.40 \%$ & & & & \\
\hline A. ovalis (EU930048) & $3.24 \%$ & $3.17 \%$ & $3.90 \%$ & & & \\
\hline A. ovalis (this study) & $3.06 \%$ & $2.87 \%$ & $3.72 \%$ & $0.29 \%$ & & \\
\hline A. wrighti (EU417963) & $2.22 \%$ & $2.16 \%$ & $2.40 \%$ & $3.60 \%$ & $3.41 \%$ & \\
\hline
\end{tabular}

Intra-specific distances are in bold.

SSU rRNA, small subunit ribosomal RNA. 



Fig. 3. Morphology and infraciliature of Apokeronopsis ovalis from live $(A-F)$ and after protargol impregnation $(G-L)$. Dorsal $(A, F)$ and ventral (C-E) views of live, (C) arrow indicates the contractile vacuole; B-D, Body shape slightly contractile and flexible; $E$, $F$, Arrow and arrowhead mark the two types of granules, respectively; double-arrowhead indicates the dorsal cilia; Ventral (G-I, K, L) and dorsal (J) views of the protargol-impregnated specimen; $G$, General ciliature of the specimen; $H$, Two frontoterminal cirri, arrows indicate cirri near the distal end of the adoral zone; I, Arrow denotes macronuclear nodules; J, Arrows indicate dorsal kineties, usually three; K, Frontal (bicorona); L, J-shaped transverse cirri. Scale bars: $100 \mu \mathrm{m}$.

Korean). Shao et al. (2008) suggested that the body colour of A. ovalis is possibly reflected by green or yellow-greencoloured cortical granules. However, the cellular color of the Korean population is colourless and the cells have both of colourless and yellow-green coloured type II granules, which the coloured granules are distributed sparsely in the whole body. The colour of the granules in the family Pseudokeronopsidae has been known as an important characteristics (Berger, 2006; Song et al., 2006), however, Li et al. (2008) reported that the colours in A. bergeri were variable from 
yellow-brown to yellow-green, and that the colours can even be changed to dark-red in cultured cells. Therefore the colour of the cortical granules in A. bergeri and A. ovalis should be treated carefully as a diagnostics for species identification.

The SSU rRNA gene sequence of $A$. ovalis is $1,751 \mathrm{bp}$ in length (GenBank accession no: JF718645). Inter-specific pairwise distances between $A$. ovalis and congeners are more than $2 \%$, however, the intra-specific distance within A. ovalis is $0.29 \%$ (Table 3 ).

\section{ACKNOWLEDGEMENTS}

This work was supported by an Inha University grant.

\section{REFERENCES}

Berger H, 2006. Monograph of the Urostyloidea (Ciliophora, Hypotricha). Springer, Dordrecht, pp. 1-1304.

Borror AC, Wicklow BJ, 1983. The suborder Urostylina Jankowski (Ciliophora, Hypotrichida): morphology, systematics and identification of species. Acta Protozoologica, 22:97-126.

Chen X, Huang J, Song W, 2011. Ontogeny and phylogeny of Metaurostylopsis cheni sp. n. (Protozoa, Ciliophora), with estimating the systematic position of Metaurostylopsis. Zoologica Scripta, 40:99-111.

Foissner W, 1991. Basic light and scanning electron microscopic methods for taxonomic studies of ciliated protozoa. European Journal of Protistology, 27:313-330.

Hall TA, 1999. BioEdit: a user-friendly biological sequence alignment editor and analysis program for Windows 95/98/ NT. Nucleic Acids Symposium Series, 41:95-98.

Jeanmougin F, Thompson JD, Gouy M, Higgins DG, Gibson TJ, 1998. Multiple sequence alignment with Clustal X. Trends in Biochemical Sciences, 23:403-405.

Kahl A, 1932. Urtiere oder Protozoa I: Wimpertiere oder Ciliata (Infusoria), 3. Spirotricha. Die Tierwelt Deutschlands, 25: 399-650.

Kimura M, 1980. A simple method for estimating evolutionary rates of base substitutions through comparative studies of nucleotide sequences. Journal of Molecular Evolution, 16: 111-120.

Kumar S, Tamura K, Nei M, 2004. MEGA3: integrated software for molecular evolutionary genetics analysis and sequence alignment. Briefings in Bioinformatics, 5:150-163.

Li L, Song W, Warren A, Al-Rasheid KAS, Roberts D, Yi Z,
Al-Farraj SA, Hu X, 2008. Morphology and morphogenesis of a new marine ciliate, Apokeronopsis bergeri nov. spec. (Ciliophora, Hypotrichida), from the Yellow Sea, China. European Journal of Protistology, 44:208-219.

Liu W, Li J, Gao S, Shao C, Gong J, Lin X, Liu H, Song W, 2009. Morphological studies and molecular data on a new marine ciliate, Apokeronopsis sinica n. sp. (Ciliophora: Urostylida), from the South China Sea. Zootaxa, 2005:57-66.

Long H, Liu H, Liu W, Miao M, Hu X, Lin X, Song W, 2008. Two new ciliates from Hong Kong coastal water: Orthodonella sinica $\mathrm{n}$. sp. and Apokeronopsis wrighti n. sp. (protozoa: ciliophora). The Journal of Eukaryotic Microbiology, 55:321330.

Lynn DH, 2008. The ciliated protozoa: characterization, classification, and guide to the literature. Springer, New York, pp. 1-605.

Medlin L, Elwood HJ, Stickel S, Sogin ML, 1988. The characterization of enzymatically amplified eukaryotic 16S-like rRNA-coding regions. Gene, 71:491-499.

Shao C, Hu X, Warren A, Al-Rasheid KAS, Al-Quraishy SA, Song W, 2007. Morphogenesis in the marine spirotrichous ciliate Apokeronopsis crassa (Claparède \& Lachmann, 1858) n. comb. (Ciliophora: Stichotrichia), with the establishment of a new genus, Apokeronopsis n. g., and redefinition of the genus Thigmokeronopsis. The Journal of Eukaryotic Microbiology, 54:392-401.

Shao C, Miao M, Li L, Song W, Al-Rasheid KAS, Al-Quraishy SA, Al-Farraj SA, 2008. Morphogenesis and morphological redescription of a poorly known ciliate Apokeronopsis ovalis (Kahl, 1932) nov. comb. (Ciliophora: Urostylida). Acta Protozoologica, 47:363-376.

Song W, Warren A, Roberts D, Wilbert N, Li L, Sun P, Hu X, $\mathrm{Ma} H, 2006$. Comparison and redefinition of four marine, coloured Pseudokeronopsis spp. (Ciliophora: Hypotrichida), with emphasis on their living morphology. Acta Protozoologica, 45:271-287.

Sonnenberg R, Nolte AW, Tautz D, 2007. An evaluation of LSU rDNA D1-D2 sequences for their use in species identification. Frontiers in Zoology, 4:6.

Yi Z, Song W, Shao C, Warren A, Al-Rasheid KAS, Roberts DM, Miao M, Al-Quraishy SA, Chen Z, 2008. Phylogeny of some systematically uncertain urostyloids-Apokeronopsis, Metaurostylopsis, Thigmokeronopsis (Ciliophora, Stichotrichia) estimated with small subunit rRNA gene sequence information: discrepancies and agreements with morphological data. European Journal of Protistology, 44:254-262.

Received April 15, 2011 Accepted May 12, 2011 